\title{
Sciendo
}

DOI: 10.2478/RAE-2019-0032 Review of Artistic Education no. 182019 287-292

\section{PROBLEMS GENERATED BY POOR SUPPORT OF YOUNG TALENTED PEOPLE}

\author{
Ona Ionica Anghel ${ }^{309}$
}

\begin{abstract}
The subject of supporting talented young people through educational strategies and educational policies is more and more concerning for the researchers in the area of psycho-pedagogy of excellence. The problems solved by the policies and strategies of supporting talented students have a double nature: some have of a moral and personal nature, invoking the right to equitable education for each and the maximum development of talent for oneself, others have social and economic nature. In order for a person to be creative, to offer innovative solutions to various technical, environmental, social, cultural, etc. a partnership is needed: the talented person and his supporters - the family, the school, the economic environment, the country where he lives. The paper discusses the two major categories of issues generated by the lack of support of young talent, insisting on the phenomena of intelligence migration.
\end{abstract}

Key words: talent, giftedness, support, brain drain, brain waist

\section{Introduction}

The idea that the economic development of a country depends on its capital in human resources is often supported. However, it is fair to expect that the high-performing human resource will choose to offer its services where they are demanded, respected and appreciated at their true value. In a global economy without borders, including the job market, it is to be expected that talented young people are supported and promoted no matter where they choose to practice their craft, this way they may be persuaded to choose the country whose language they speak to gradually develop their talent. Without any kind of support they will certainly choose something else. In Romania, we have been confronted for a long time with the phenomenon of high performing young people migrating to more friendly job markets that offer a remuneration correlated to the value of work done and a high standard of living.

The emigration of highly skilled people leads to other problems that are detrimental to the country of origin: on one hand it is the inability to recover the investments made in their education and on the other the difficulties in recruiting a highly competent work force for the national companies or corporations willing to invest in Romania. By default, economic progress is slowing down. In Romania, the loss of grey matter also happens in other ways too, namely by the inability of some of the graduates to find a job adequate to the skills they possess. In the specialized literature, this phenomenon is known as "brain

\footnotetext{
309 Lecturer PhD., “George Enescu” National University of Arts from Iaşi, Romania, email: ona_anghel@yahoo.com
} 
waste". Most of the graduates who after repeated and failed attempts to achieve their professional aspirations in the country, will eventually decide to emigrate.

\section{Problem I: Uncultivated talent can be lost}

The topic of supporting gifted and talented children and young people has been talked about for several decades in Romania as well. Prominent academics highlight the need for a differentiated approach to the education of this special segment of the population as a right that society is responsible for enforcing due to the fact that it is dependent on the capital of human talent at its disposal. Promoting this capital, thus becomes one of the most important strategic objectives of the society (Creţu, C., 2006). For a person to be creative, to provide innovative solutions to various technical, environmental, social, cultural, etc, issues, a partnership is needed: between the talented person and its supporters. Along with this, the state has a big role to play because if the state aspires to progress it is its responsibility to provide support to those who are making this progress possible. The state is not the only one participant responsible for the fulfilment of the gifted: the family, the school, the economic environment will also contribute to this mission.

If for a long period of time the myth that the gifted can use their talent to succeed was accepted as true, the need for an educational intervention in the development of their potential is undeniable today. Apart from educational support, the need for emotional support is also required, considering that gifted adolescents and young people may have some unique emotional needs and adaptation problems due to the fact that they sometimes perceive themselves to be different from others which can lead to extreme behaviours ranging from academic failure to suicidal acts. Hyatt L.A. and Cross T.L., review of some of the traits that determinate such behaviours as: boredom, increased sensitivity in perceiving reality, preoccupation with mankind's global issues which leads to the self-identification with said problems, difficulties in defining their own personal identity and in building a positive self-image, perfectionism, having discouraging life experiences such as unappreciated creativity, etc. (Hyatt L.A. and Cross T.L. in Shavinina, 2009).

Investing in the education of gifted and talented people, not only financially, must continue past the end of secondary studies. Most of the studies done on the issue of educating gifted people have been mostly focused on the age of childhood, puberty or adolescence and much less on youth or adulthood. Differentiated educational intervention must be continued all the way through university studies. This last step towards adulthood is extremely important as it will heavily influence both the success in professional and family life. The uncultivated talent is lost even at this age. There have been noticed frequent cases of Olympians that are no longer performing at a high level in their work, as somewhere on the way from school to professional life, their talents have been lost (Creţu, 1997). In the same register, Ziegler discusses the case of 
adolescents identified as gifted and talented but who do not get high-level prizes, such as the Nobel Prize, for example, or those subjects who were rejected by Terman's study but ended up being Nobel Prize-winners (as example, scientists Shockley and Alvarez), these being the unidentified gifted persons (Ziegler, 2009).

\section{Problem II: The migration of intelligence}

The Royal Society of London first used the term "brain drain" to describe the departure of European scientists and technicians to the US and Canada in the early 1950s. The term "brain drain" refers to the international transfer of resources in the form of human capital and is particularized in the form of migration of highly educated people from developing countries to developed countries (Ferro, A., 2004). This definition underlines the irony of migration in our time, namely that it refers to the departure of the part of the population that a developing country can not afford to lose, namely highly qualified and educated people.

Since the 1960s, the phenomenon has captured the attention of many scholars in economics and politics and studies on the subject have become more and more numerous. The results lead to the conclusion that "brain drain" has two main negative effects: the country of origin loses human capital thus being devoid of the main engine for economic growth and at the same time losing much of the public investment made to educate that human capital (Glăvan, B., 2008; Marga, 2007; Vaknin, S., 2006; Lowell, Findlay, 2001). In this way the losses of the country from which they migrate are at least double: on the one hand these losses come from the diminishing of the productivity potential and on the other hand from the fiscal point of view, where not only the investments made in education will yield no return, but also the number people who will be future tax payers will narrow down.

The phenomenon is viewed today from other perspectives. If by the 1990s the most frequent interpretation was in terms of large losses for the country of origin and hefty gains for the country people are leaving to, after this period other facets were shown. "The brain drain" can be viewed not only from the perspective of the country from which the people are migrating, but also from the perspective of the welcoming country that says brain is also brain gain and from the perspective of the migrant who argues his decision as "better brain drain than brain waste". In this way, the intelligence exodus also has some positive consequences: educational opportunities that would not be available in the country of origin, an influx of skills transfers, the return of some people with new experiences and skills, the circulation of brilliant minds (Wickramasekara, P. 2002, quoted by Marga, 2007). All of these have a probable low occurrence rate because once they leave, very few of the intellectuals return, and those who do return do not offset the huge losses of the country of origin. 
In the context of an analysis of youth support policies in Romania, a team of researchers debates the brain drain phenomenon and notes both an external loss - equivalent to the concept of "brain drain" and an internal one - equivalent in the literature with "brain waste" (Helsingius U., Bois-Reymond du, M., Nurse, L., Chan, V., Pais, J., M., Trestieni Ion, D., 2000). "Brain waste" describes the skill wastage that happens when highly trained specialists migrate to certain jobs that do not require the skills and experience they have gathered in past jobs. (Dracea, R., Cristea, M., Mitu, N., 2010).

The causes that lead to the exodus and/or waste of high intelligence and professional competence are frequently discussed and analyzed. The most cited are the local economic, social, political conditions, etc, which do not allow for the professional and financial fulfilment of highly qualified persons.

Ferro, A. conducts a study targeting IT specialists moving from Romania to other countries. The main causes of migration are related to career opportunities, whether it is a real opportunity to advance in a career $(36 \%$ of respondents), or that the salary is much higher than one obtained at a similar job in Romania (5\%), or to access a more interesting job (5\%). Reasons for career opportunities are closely followed by the desire to have a better quality of life (21\%). The study done by the Italian author comes to the conclusion that the intelligence exodus in Romania is "a natural consequence for a country that does not use the potential of its people and suppresses the aspirations for professional realization." (Ferro, A., 2004, p.15)

Other studies also confirm that the reasons for emigration most often invoked are the type of jobs that can be accessed in Romania which are not as challenging as those outside the country or insufficient remuneration for the services offered. Thus, Popescu, D., Pătrașca and M., Chivu, I. investigating the reasons why Romanian researchers choose to leave, claim that three quarters of the subjects declare as the main reason the lack of or the small number of opportunities to perform at their maximum potential, and $68 \%$ low wages. Another important reason why research scientists choose to work across borders is related to the insufficient allocation of research funds. In the field of engineering $53 \%$ of respondents consider this reason extremely important and 20\% very important. (Popescu, D., Pătrașca, M., Chivu, I., 2006, p.198 -199)

Quantifying the number of talented and high-end professional people migrating from Romania is an extremely difficult task. Different sources of information offer only partial data given that the phenomenon is too volatile to be numerically determined, and it is difficult to extract from the total number of migrations the number of those who would qualify under the phenomenon of brain drain.

\section{Conclusions}

All identified studies, even those that discuss the positive aspects of the phenomenon of brain drain, conclude that the phenomenon affects the country 
from which it originates by reducing its development capacity. Some researchers recommend a course of action to mitigate the problem. Marga cites the "Constructing Knowledge Societies" report, which lists the following measures: the setting of clear rules by the institutions facilitating mobility programs to ensure the return of professionals trained from external funds; increasing confidence in diplomas obtained in foreign institutions; the inclusion in scholarships of travel funds or allowances for the acquisition of equipment and materials necessary for the continuation of the studies commenced abroad; the preference to send students to top universities in countries with a saturated job market (eg India); creating a favourable work environment for researchers and specialists (Marga, 2007, p.13)

All these measures are of a generalized nature, and the phenomenon is contextual and should be treated as such. Its in-depth investigation from different perspectives, depending on the specifics of different fields of study (economic, political, educational) is not only necessary but mandatory. Regardless of the approach, it is necessary to consider the recognition of the unalienable rights and freedoms of the person and the recognition and acceptance of open competition on the jobs market.

The researcher from Cluj believes that in Romania the phenomenon of "brain drain" can be limited only under the conditions of a sustained international cooperation and proposes in this respect some reference frameworks for possible strategies that should be employed by universities: "the establishment of top university campus franchises, the liberalization of recruitment procedures for teachers from abroad, efficient mobility of managers, creation of joint research units in cooperation with Western universities, expansion of investments for professional training, scientific research and professional expertise based on the relationship between companies and universities. (Marga, 2007, p. 15).

Moreover, policies to support the gifted and dedicated people, and the particularization of educational policies as public policies, must be understood, formulated and implemented beyond the big decisions and the macro-strategy. It is even appropriate that these policies are formulated at the institutional level, the school institutions being often closer to the direct beneficiaries (pupils or students) and able to make decisions determined by the local economic specificity.

\section{References}

1. Creţu, C. (1997) Psihopedagogia succesului, Ed. Polirom, Iaşi.

2. Creţu, C. (2006) Global Curriculum: Concept Development, Emerging Theories and Curriculum Policy Issues, in Crişan, A. (Ed), Current and Future challenges in curriculum Development: Policies, Practices and Networking for Change, Humanitas Educaţional, Bucureşti 
3. Dracea, R.., Cristea, M., Mitu, N. (2010) Migrația şi competiția fiscală. Implicații la nivelul Uniunii Europene,[Migration and tax competition. Implications at the level of the European Union] http://www.fiscalitatea.manager.ro/migratiaprocente

20siprocente20competitiaprocente20fiscalaprocente20implicatiiprocente20lapro cente20nivelulprocente20uniuniiprocente20europene-283/ , downloaded on august 2018.

4. Ferro, A. (2004) A picture of a Highly Skilled Labour Migration from Romania, International Roundtable Brain Drain and the Academic and Intellectual Labour Market in South East Europe, UNESCO-CEPES, Bucharest, http://www.ad-astra.ro/library/papers/Aferro_Brain_Drain.pdf, downloaded on august 2018.

5. Glăvan, B. (2008) Brain Drain: A Management or a Property Problem?, American Journal of Economics and Sociology, October 2008, 719-737.

6. Helsingius U., Bois-Reymond du, M., Nurse, L., Chan, V., Pais, J., M., Trestieni I., D. (2000) Youth Policy in Romania, Report by an International Group of Experts Appointed by Council of Europe, Budapesta, Council of Europe

http://www.coe.int/t/dg4/youth/Source/IG_Coop/YP_Romania_en.pdf downloaded on august 2018.

7. Hyatt, L., A., Cross, T. L. (2009) Understanding Suicidal Behavior of Gifted Students: Theory, Factors and Cultural Expectations, in Shavinina, L., V., (Ed.), International Handbook on Giftedness, 537 - 557, Springer Sciece+Business Media B.V., Canada.

8. Lowell, F. (2001) Migration of Highly Skilled Persons from Developing Countries: Impact and Policy Responses, International Migration Papers, 44, Geneva: International Labor Ofice, International Migration Branch.

9. Marga, A. (2007) The University of the 21st Century. Challenges, Address to the annual meeting of the Alliance of Universities for Democracy (AUDEM), Cluj, November 4, 2007, www.audem.org/docs/word/conference18_keynoteaddress.20071107.doc, downloaded on march 2015.

10. Popescu, D., Patrasca, M., Chivu, I. (2006) Tendencies of International Career of Romanian Researchers: Brain Drain?, Journal of Aplied Quantitative Methods, 1(2) winter 2006, 194 - 209.

11. Prelipceanu, R. (2008) The New Migration Patterns Of Educated Romanians To The EU: What Challenges For The Individuals And For The Nation-State?, Romanian Journal Of European Affairs, 8(4), 75 -87.

12. Vaknin, S. (2006) Meritocracy and Brain Drain, http://www.globalpolitician.com/22342-business, downloaded on march 2015.

13. Ziegler, A (2009) Research on Giftedness in the 21st Century, in Shavinina (Ed.) International Handbook on Giftedness, 1509 -1524, Springer Sciece+Business Media B.V., Canada. 